DOI: https://doi.org/10.47405/mjssh.v6i11.1154

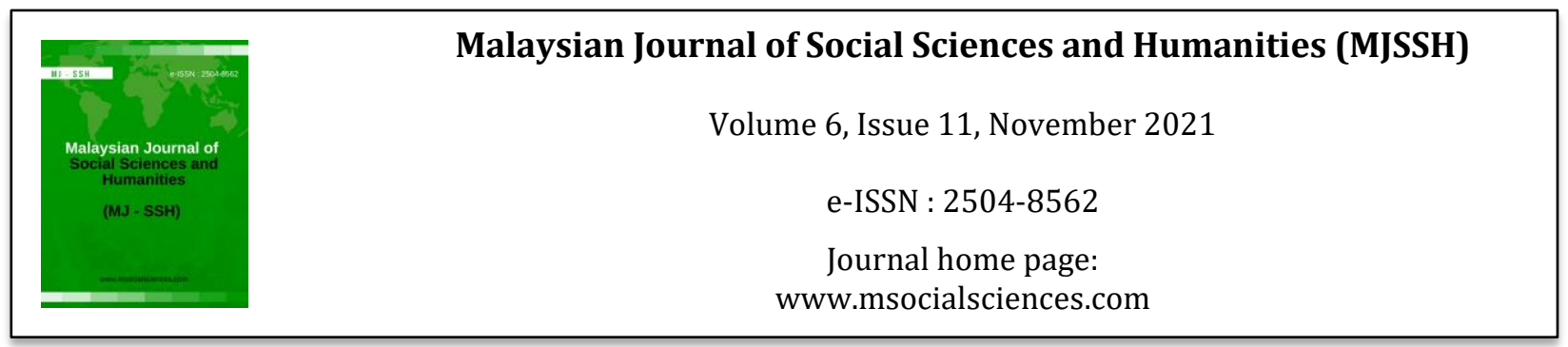

\title{
Peranan Komunikasi dalam E-Pembelajaran:Impak Terhadap Prestasi Pembelajaran Mahasiswa Pasca Covid-19
}

\author{
Muhammad Shahrul Sazlee Bin Mohd Safuan Lee ${ }^{1}$, Ishak Bin Abd Rahman', Azmi Bin Aziz ${ }^{2}$ \\ 1Fakulti Ekonomi dan Pengurusan, Universiti Kebangsaan Malaysia (UKM), Malaysia \\ 2Fakulti Sains Sosial dan Kemanusiaan, Universiti Kebangsaan Malaysia (UKM), \\ Malaysia
}

Correspondence: Azmi Bin Aziz (abaz@ukm.edu.my)

\begin{abstract}
Abstrak
Kajian ini bertujuan untuk mengkaji impak peranan komunikasi atas talian dalam E pembelajaran kepada prestasi pembelajaran mahasiswa,Pasca Covid 19. Kajian ini akan mengkaji peranan komunikasi atas talian dari faktor interaktiviti, pengurusan masa dan juga peningkatan pengetahuan ICT dan hubungannya dengan prestasi pembelajaran mahasiswa dalam E pembelajaran sepanjang pasca Covid 19. Kajian ini dijalankan oleh pengkaji dengan tujuan untuk mengkaji perhubungan faktor-faktor tersebut dalam komunikasi semasa E pembelajaran dan juga hubungannya dengan E pembelajaran. Seramai 154 orang responden telah dipilih secara rawak dalam kalangan mahasiswa mahasiswi Universiti dan Institusi Pendidikan Tinggi secara meluas di dalam Malaysia. Analisis Deskriptif berbentuk Pie Chart dan juga analisis inferensi seperti Ujian Kebolehpercayaan Cronbach Alpha dan Ujian Regresi Berganda telah digunakan sebagai kaedah untuk menganalisis data seterusnya mendapatkan hasil atau dapatan kajian ini.
\end{abstract}

Kata kunci: komunikasi atas talian, e-pembelajaran, pengurusan masa, interaktivi

\section{The Role of Communication in E-Learning: Impact on Post-Covid 19 Student Learning Performance}

\begin{abstract}
This study aims to examine the impact of the role of online communication in E learning to student learning performance Post Covid 19. This study will examine the role of online communication from interactivity factors, time management and also improvement of ICT knowledge and its relationship with student learning performance in E learning throughout post Covid 19. This study was conducted by the researcher with the aim of examining the relationship of these factors in communication during $E$ learning and also its relationship with $E$ learning. A total of 154 respondents were randomly selected among undergraduates of Universities and Higher Education Institutions widely in Malaysia. Descriptive analysis in the form of Pie Chart as well as inferential analysis such as Cronbach Alpha Reliability Test and Multiple Regression Test have been used as methods to analyze the data and subsequently obtain the results or findings of this study.
\end{abstract}

Keywords: online communication, e-learning, time management, interactivity 


\section{Pengenalan}

Komunikasi adalah satu kegiatan atau perlakuan yang terjadi sepanjang hari, dari terbitnya matahari sehingga terbenamnya matahari (Rahmanto, 2004). Manusia sentiasa menggunakan komunikasi dalam memudahkan segala urusan dan aktiviti. Komunikasi merupakan satu kebolehan ataupun kemahiran yang paling asas dalam diri manusia (Khemesh, 2017). Manusia dilahirkan dan diajar dengan komunikasi sejak mereka lahir lagi sebagai cara untuk menyatakan isyarat kepada sesuatu keinginan mereka .Komunikasi juga adalah satu asas kepada kebolehan atau keinginan untuk terus hidup seseorang manusia (survival) (Khemesh, 2017). Manusia memerlukan kemahiran komunikasi untuk meneruskan hidup seperti keperluan untuk berbicara dalam mendapatkan sesuatu atau menyatakan sesuatu keperluan hakiki. Hal ini kerana komunikasi adalah satu proses penerimaan dan pemprosesan maklumat dan kefahaman seseorang dari individu ke individu (Keyton, 2011). Pernyataan berkenaan komunikasi sebagai "survival skills" ini dapat dibuktikan dengan penerangan dari teori segi tiga Abraham Maslow yang menerapkan berkenaan keperluan asas manusia. Merujuk segitiga Maslow, keperluan yang berada di dua tingkat yang paling diperlukan sebagai keperluan asas manusia ialah keperluan hakiki seperti makanan dan juga keperluan keselamatan seperti bantuan kecemasan dari polis dan juga doktor (Mc Leod, 2018). Jika dilihat dari aspek keselamatan, seseorang individu harus berkomunikasi dengan pihak keselamatan seperti polis untuk mendapatkan bantuan keselamatan. Dari sudut pengurusan, komunikasi juga telah disenaraikan dalam kedudukan 10 tertinggi dalam kemahiran pengurusan yang mempunyai impak positif terhadap keselamatan (Bentley \& Haslam, 2001). Komunikasi adalah satu pencetus kepada prestasi yang cemerlang ataupun sebaliknya. Jika dilihat dari konteks sebuah organisasi, komunikasi keorganisasian ialah antara pemangkin utama dalam merancang dan membentuk perancangan strategik pembangunan modal insan sesebuah organisasi (Sulaiman \& Mahbob, 2015). Komunikasi keorganisasian amatlah penting dalam memangkin kecekapan sesebuah organisasi (Sulaiman \& Mahbob, 2015). Komunikasi dalam sesuatu organisasi juga dianggap sebagai satu komunikasi kesaksamaan di mana kesemua pihak di dalam organisasi mendapat kepentingan yang sama (Rahmanto, 2004). Antara peranan komunikasi dalam organisasi ialah dalam setiap proses komunikasi perlulah mempunyai hubungan kemanusiaan yang menyangkut keperibadian, sikap dan tingkah laku kepada pihak-pihak yang terlibat. Selain itu komunikasi juga perlulah berbentuk "persuasive" ataupun memujuk bagi memberikan motivasi kerja, bertanggungjawab dan juga produktif (Rahmanto, 2004). Motivasi dan prestasi kerja amat berkait rapat dalam sesebuah organisasi (Kinlaw, 1986).

\section{Komunikasi Atas Talian dalam Proses E-Pembelajaran Semasa Covid 19}

"Komunikasi atas talian" ialah satu frasa yang merujuk kepada pembacaan, penulisan dan berkomunikasi melalui rangkaian internet dan komputer (Warschauer, 2001). Tujuan komunikasi atas talian adalah sama seperti komunikasi secara bersemuka, di mana tujuannya adalah untuk menjalin ikatan rapat, bertukar maklumat, mendengar antara satu sama lain dan memahami antara satu sama lain (Alawamleh et al., 2020). Apabila pensyarah atau pemberi arahan berkomunikasi bersama dengan pelajar sama ada secara bersemuka ataupun menggunakan platform atas talian, tujuannya tetap sama iaitu memberi pengetahuan, meningkatkan kefahaman dan membina satu perhubungan.(Alawamleh et al, 2020). Komunikasi di dalam sektor pendidikan perlu dikaji lebih mendalam berkenaan komunikasi antara pensyarah dan pelajar dalam meningkatkan kualiti dan pengalaman pengajaran untuk membina satu sistem pembelajaran yang positif (Alawamleh et al., 2020). Selain dari komunikasi antara pensyarah dan pelajar, komunikasi antara pelajar sesama pelajar juga penting dalam komunikasi di atas talian (Bernard et al., 2009). Sebagai contoh semasa pandemik Covid 19 ini pelajar tidak dapat berkomunikasi tentang tugasan berkumpulan secara bersemuka. Hal ini penting karena setiap saat semua orang atau kelompok sudah tentu melakukan interaksi (Nur Inah, 2013). Platform atas talian dapat digunakan sebagai cara untuk berkomunikasi secara kumpulan di atas talian. Pembelajaran secara berkumpulan di atas talian dapat mewujudkan persekitaran yang ideal di mana interaksi antara pelajar memainkan peranan yang penting dalam proses pembelajaran atau perbincangan (Lipponen et al., 2002).Walaupun begitu, apabila sesuatu aktiviti itu memerlukan kolaborasi, pembelajaran secara atas talian akan menyebabkan masalah sesetengah pelajar yang tidak memberi kerjasama secara aktif 
dalam penyertaan (Chiong \& Jovanovic 2012). Hal seperti ini akan mewujudkan batasan komunikasi dalam pembelajaran.

\section{Objektif Kajian}

i. Mengkaji impak peranan faktor pengurusan masa dalam komunikasi E-pembelajaran dan perhubungannya kepada prestasi mahasiswa pasca Covid 19.

ii. Mengkaji impak peranan faktor interaktiviti dalam komunikasi E-pembelajaran dan perhubungannya kepada prestasi mahasiswa pasca Covid 19.

iii. Mengkaji impak peranan faktor Teknologi Maklumat dan Komunikasi (ICT) dalam komunikasi E-pembelajaran dan perhubungannya kepada prestasi mahasiswa pasca Covid 19.

\section{Persoalan Kajian}

i. Adakah masalah-masalah komunikasi semasa proses pembelajaran atas talian mempengaruhi prestasi pembelajaran mahasiswa?

ii. Adakah kualiti dan kaedah penyampaian komunikasi semasa e pembelajaran mempengaruhi prestasi pembelajaran mahasiswa?

iii. Adakah terdapat kelebihan komunikasi atas talian yang dapat mempengaruhi prestasi pembelajaran mahasiswa?

\section{Sorotan Kajian}

Interaksi adalah satu perlakuan antara individu (Abrami et al., 2011). Di dalam E-pembelajaran secara atas talian, interaktiviti bukan hanya satu dimensi yang memfokuskan kepada arahan secara multimedia yang lebih dianggap "interaktif" berbanding pembelajaran secara Tradisional. Ianya mungkin mempunyai definisi yang lebih tepat (Michael, 2000). Rose (1999) menyatakan bahawa dunia masih belum mempunyai maksud sebenar berkenaan dengan interaktiviti dalam satu arahan. Interaktiviti yang dimaksudkan di dalam kajian Michael (2000) lebih menjurus kepada interaksi dan interaktiviti sebagai satu bentuk arahan (Michael, 2000).Interaktiviti dalam arahan yang mempunyai batasan waktu dan jarak adalah satu pembolehubah yang menjadi tanda tanya dalam kejayaan pembelajaran jarak jauh seperti E pembelajaran (Michael, 2000). Michael (2000) kemudiannya menerangkan interaktiviti sebagai satu bentuk gelung mesej. Entiti adalah gelung interaktiviti di antara pelajar, pengajar, komputer dan media lain yang mampu menerima dan menghantar maklumat .Contoh corak gelung interaktiviti antara pelajar dan pensyarah, pensyarah dan pelajar dan juga pelajar dan program komputer yang telah disediakan (Michael Yacci 2000). Pengkaji-pengkaji lain juga telah menerangkan berkenaan konsep gelung peredaran interaktiviti dalam konsep yang lain. Contohnya, Alessi dan Trollip (2001) menyatakan bagi mencapai tahap kefahaman dalam proses pembelajaran atas talian, sesuatu komunikasi dalam talian itu perlu mempunyai interaktiviti yang tinggi antara manusia. Tiga interaksi terpenting dalam proses pembelajaran atas talian ialah interaksi antara pelajar dan pengajar, pelajar dan pelajar dan juga pelajar dan kursus (Bernard et al., 2009). Interaktiviti yang tinggi akan meningkatkan kemampuan untuk fokus seseorang manusia ke atas persekitaran tugasan yang diberi atas talian (Heinich et al., 1989). Interaksi yang tinggi dalam proses E-pembelajaran juga dikaitkan dengan meningkatkan motivasi dan kepuasan seseorang dalam pembelajaran atas talian (Shuollo et al., 2007). Kualiti dalam interaksi juga menentukan kualiti dalam kursus dan juga prestasi, gred dan kepuasan seseorang pelajar (Apanna, 2008). Dalam satu kajian yang dijalankan oleh Y AlQatahni dan A Rajhkan (2020) yang menentukan berkenaan dengan faktor kejayaan kritikal dalam faktor pengurusan E-pembelajaran semasa pandemik Covid 19, sokongan merupakan salah satu titik kritikal dalam kejayaan E-pembelajaran seperti faktor suasana pembelajaran dan interaktiviti dalam pembelajaran. 


\section{Pengurusan Masa Dalam Komunikasi Atas Talian}

Pengurusan masa adalah satu terma yang diguna secara meluaskan dalam menguruskan sesuatu aktiviti (Tomas \& Arnost, 2009). Setiap aktiviti yang dilakukan memerlukan pengurusan masa yang sistematik dalam menjadikannya satu aktiviti yang dapat diselesaikan mengikut rancangan. Penggunaan teknologi komunikasi untuk E-pembelajaran, seperti teknologi komunikasi yang lain, dapat mengakibatkan pembuangan masa jika tidak digunakan secara tepat (Tomas \& Arnost 2009). Pengurusan komunikasi atas talian semasa E-pembelajaran juga perlu diuruskan dengan betul bagi mengelakkan komunikasi yang disampaikan menjadi tidak telus ataupun tidak tepat. Dalam satu kajian berkenaan dengan Ebola Outbreak dalam Republik Demokratik Timur pada tahun 2018, maklumat tersebar dengan maklumat yang salah dan tidak benar. Beberapa pengkaji meragui dan berselisih pendapat berkenaan dengan maklumat yang disebarkan akan menimbulkan salah faham dan kepercayaan autoriti (Vinck et al., 2019). Mereka mempercayai komunikasi atas talian itu perlu benar dan tepat, diedarkan dalam masa yang tepat dan secara telus dan rahsia. Kajian ini juga mendapat perhatian kepada satu kajian yang telah dijalankan oleh Gerrard Goggin dan Katie Ellis (2020) apabila mereka merasakan pernyataan ini boleh dikaitkan sebagai antara risiko yang akan dihadapi dalam komunikasi atas talian jika tidak digunakan dengan tepat ketika COVID 19. (Gerrard Goggin \& Katie Ellis 2020). Kajian ini memfokuskan kepada pernyataan "diedarkan dalam masa yang tepat" oleh Vinck et al. (2019) yang dapat dipersamakan dengan keperluan untuk para pelajar menguruskan masa dengan tepat semasa berkomunikasi dalam E pembelajaran semasa Covid 19 untuk mengelakkan kesalahfahaman maklumat dan krisis berkomunikasi di atas talian. Antara krisis komunikasi seperti kesalahfahaman antara pelajar boleh menyebabkan pergaduhan dan penggunaan komunikasi yang sepatutnya dalam masa yang tepat juga adalah satu keperluan yang wajib. Pelajar perlulah berkomunikasi secara efektif ketika E-pembelajaran. Antara isu yang dapat dielakkan berkenaan pengurusan masa untuk menjamin komunikasi yang efektif adalah tidak menghantar atau membalas mesej dengan lambat (Reddy \& Gupta, 2020). Komunikasi yang efektif dapat membantu dalam meningkatkan prestasi pelajar (Reddy \& Gupta, 2020). Menurut satu kajian dari Dennis Kira dan Saade (2006), faktor masa adalah salah satu sebab pelajar lebih gemar untuk menghadiri kelas atas talian. $60 \%$ pelajar menyatakan Mereka amat memahami isi kandungan dengan alat bantu belajar yang digunakan (Dennis Kira \& Saade, 2006). Masa yang digunakan untuk menghadiri kelas atas talian juga adalah salah satu faktor dalam pencapaian pelajar. Satu kajian telah dijalankan berkenaan dengan satu ujian kepada pembelajaran secara maya dan secara bersemuka. Antara penyebab mengapa keputusan ujian pelajar yang belajar secara E-pembelajaran adalah rendah adalah disebabkan masa yang kurang di gunakan untuk berinteraksi di dalam kelas atas talian semasa E-pembelajaran (Brown \& Liedholm, 2002). Kelas secara bersemuka menggunakan masa selama tiga jam sekurang-kurangnya dalam seminggu untuk berinteraksi dalam kelas manakala setengah dari pelajar yang menghadiri kelas atas talian kurang menyumbangkan masa untuk berinteraksi dalam kelas atas talian (Brown \& Liedholm, 2002). Kajian ini memberi satu perspektif berkenaan hubungan Interaksi dan pengurusan masa memainkan peranan yang penting dalam prestasi pelajar.

\section{Teknologi Maklumat dan Komunikasi (ICT) dalam Komunikasi E Pembelajaran}

Organisasi dan institusi Pendidikan telah banyak melaburkan pelaburan berbentuk wang dan fizikal dalam teknologi maklumat untuk meningkatkan sistem pendidikan dan latihan melalui electronic learning (e-learning) ataupun dikenali dengan E- pembelajaran (Bates 2001). E pembelajaran adalah sistem pembelajaran dan latihan yang disampaikan melalui penggunaan teknologi maklumat dan komunikasi (ICT)yang dicorakkan untuk membantu menyokong pembelajaran kendiri dan juga matlamat organisasi (Clark \& Mayer, 2003). Kerajaan Peruvian telah membentuk satu Persatuan Teknologi Pembelajaran yang mempunyai objektif untuk memajukan ICT dalam pendidikan. (MinEdu, 2007) Salah satu objektif yang telah dipegang adalah untuk menitikberatkan pengetahuan multimedia dan teknologi maklumat dalam E- pembelajaran (MinEdu, 2007).Terdapat beberapa kajian lain yang lebih menumpukan faktor komunikasi, dan faktor teknologi dalam E-pembelajaran dan perhubungannya dengan peningkatan ICT dalam pembelajaran. Antaranya ialah Jabatan penyelidikan Amerika Syarikat 2003, Laporan Kajian Pendidikan, Bahagian Integrasi Pendidikan telah menyatakan aktiviti pembelajaran pelajar menggunakan teknologi komputer telah meningkatkan kemahiran menggunakan komputer dalam kalangan pelajar ketika membuat latihan dan sebagainya (US report 
2003). Selain itu, Wan Hussain dan Fadhilah (2017) juga telah menyatakan melalui kaedah e pembelajaran sistem pembelajaran telah menjadi semakin menarik minat pelajar, bebas dan menarik minat pelajar. Melalui kaedah ini juga pelajar lebih terdedah dengan pengetahuan ICT (Wan Hussain \& Fadhilah, 2017). Mereka juga telah menyatakan bahawa perlaksanaan E pembelajaran juga mempengaruhi aspek penyampaian (komunikasi) penyampaian, maklum balas pelajar (komunikasi) sehinggalah proses penilaian. Selain itu terdapat satu kajian dari An et al (2009) juga telah menyatakan bahawa E pembelajaran dapat meningkatkan pengetahuan ICT (An et al., 2009). Walau bagaimanapun kajian yang telah dijalankan oleh Wan Hussain dan Fadhilah telah menunjukkan peningkatan yang sederhana dalam pengetahuan ICT pelajar sepanjang proses e pembelajaran (Wan Hussain \& Fadhilah, 2017)

\section{Prestasi Pelajar Sepanjang Pandemik Covid-19}

Prestasi belajar adalah hasil yang dicapai atau dilakukan (Purwodarminto, 1994). Prestasi belajar juga dinyatakan sebagai hasil yang dicapai oleh warga belajar yang dimanifestasikan ke dalam bentuk nilai, yang diperoleh melalui evaluasi belajar sebagai cerminan penguasaan terhadap pengetahuan, keterampilan dan sikap setelah mengalami proses belajar dalam suatu periode tertentu (Tyasasih, 2004). Menurut Devi et al. (2016), faktor-faktor yang mempengaruhi prestasi belajar seorang pelajar mempunyai faktor dalaman dan luaran. Faktor dalaman adalah faktor-faktor seperti faktor psikologi, fisiologi , jasmani dan kesihatan mental pelajar. Faktor luaran pula adalah faktor cara pembelajaran di sekolah ataupun Universiti, disiplin, dan faktor luaran seperti dorongan dan pembentukan pengaruh sosial dari rakan-rakan dan juga dari pengaruh ibu bapa. Prestasi pembelajaran pelajar sepanjang pandemik Covid 19 dapat diukur melalui faktor internal dan eksternal pelajar melalui satu kajian yang telah dijalankan oleh Ahmad Elzany et al. (2020) berkenaan dengan pengalaman dalam e pembelajaran sepanjang pandemik Covid 19 dan juga tugasan secara atas talian. Kajian ini menilai persepsi pelajar dan menilai juga berkenaan dengan impak e pembelajaran kepada prestasi pelajar. Keputusan kajian ini mendapatkan keputusan yang memberangsangkan di mana Cronbach alpha kepada pemboleh ubah dalam kajian ini mendapatkan nilai yang tinggi dan boleh dipercayai iaitu 0.67. Responden yang menjawab soal selidik kebanyakannya merasakan bahawa E pembelajaran mampu meningkatkan pemahaman dan juga membantu mereka dalam berani tampil ke hadapan kerana suasana kelas atas talian. Sebahagian dari responden juga merasakan bahawa E pembelajaran membantu mereka dalam penjimatan masa. Walau bagaimanapun terdapat juga beberapa respons yang kurang memberangsangkan dari responden seperti mereka merasakan komunikasi secara diskusi yang dijalankan oleh pensyarah kurang memberi pemahaman dan boleh dipertambah baik. Satu kajian dari Arshad khaan et al. (2020) juga telah menunjukkan persepsi yang baik mahasiswa kepada peningkatan prestasi dengan menggunakan platform e pembelajaran. Kajian dari Arshad khaan et al. (2020) ini menunjukkan bahawa $59.2 \%$ pelajar merasa mampu untuk belajar menggunakan e pembelajaran kerana e pembelajaran membantu meningkatkan prestasi dalam penggunaan sistem atas talian. Sebanyak $46.2 \%$ pelajar yang mempercayai bahawa mereka boleh mencapai taraf pembelajaran yang lebih tinggi dengan menggunakan e pembelajaran yang bermaksud mereka dan yakin dan prestasi mereka meningkat dengan menggunakan e pembelajaran. Walau bagaimanapun, interaktiviti ketika pembelajaran mendapatkan peratus yang lebih rendah di mana para pelajar memerlukan interaktiviti yang tinggi di dalam proses e pembelajaran bagi mendapatkan proses e pembelajaran yang lebih bagus untuk peningkatan prestasi. Satu Teori yang berkaitan dengan peranan komunikasi dan E pembelajaran dan prestasi mahasiswa yang boleh dikaitkan adalah Teori Kelas Atas Talian yang dibentangkan oleh Hrastinski (2009). Hrastinki menyatakan untuk meningkatkan prestasi dalam pembelajaran ianya memerlukan penglibatan. Tanpa penglibatan dari pihak yang terlibat, kejayaan E-Pembelajaran tidak dapat direalisasikan Hrastinski (2009). 


\section{Kerangka Kajian Konseptual}

Pemboleh Ubah Tidak Bersandar Pemboleh Ubah Bersandar

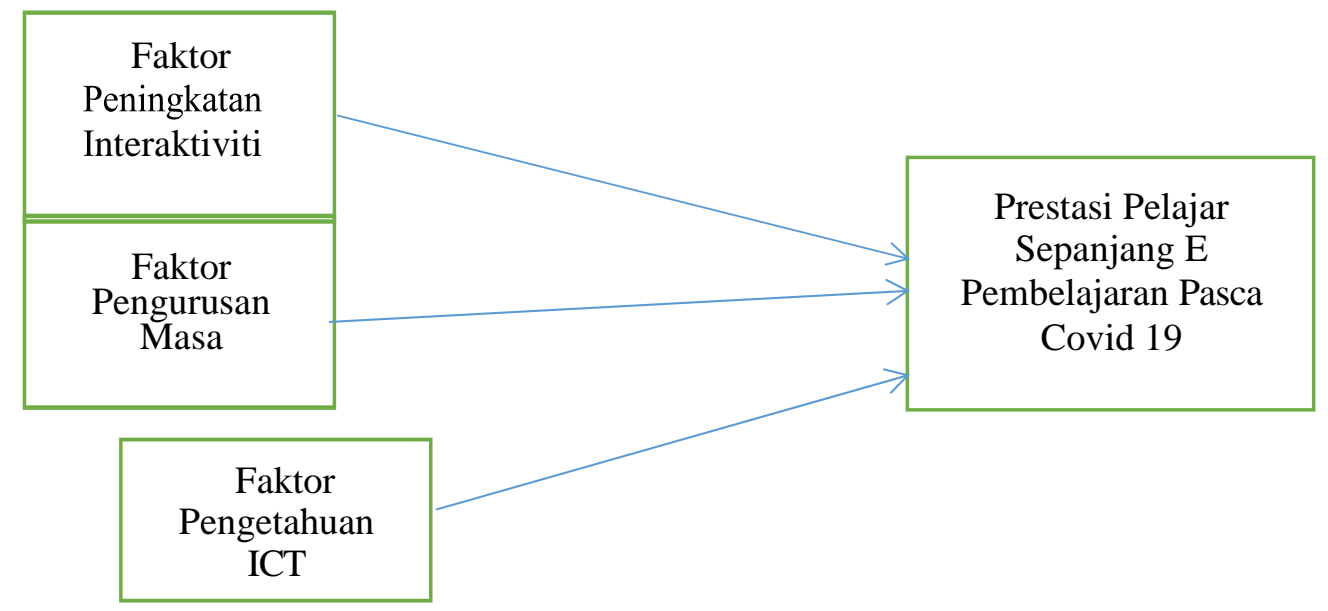

\section{Hipotesis Kajian}

H1a: Terdapat hubungan yang signifikan antara peningkatan interaktiviti dalam komunikasi e pembelajaran terhadap prestasi pelajar sepanjang Pasca Covid 19

H0a: Terdapat hubungan yang tidak signifikan antara peningkatan interaktiviti dalam komunikasi e pembelajaran terhadap prestasi pelajar sepanjang Pasca Covid 19

H1b: Terdapat hubungan yang signifikan antara pengurusan masa dalam komunikasi e pembelajaran terhadap prestasi pelajar sepanjang pasca Covid 19

H0b: Terdapat hubungan yang tidak signifikan antara pengurusan masa dalam komunikasi e pembelajaran terhadap prestasi pelajar sepanjang pasca Covid 19

H1c: Terdapat hubungan yang signifikan antara pengetahuan ICT melalui komunikasi e pembelajaran terhadap prestasi pelajar sepanjang pasca Covid 19

H0c: Terdapat hubungan yang tidak signifikan antara pengetahuan ICT melalui komunikasi e pembelajaran terhadap prestasi pelajar sepanjang pasca Covid 19

\section{Metod Kajian}

Kajian ini adalah kajian yang berbentuk tinjauan. Kaedah perlaksanaan kajian ini menggunakan data sekunder seperti kajian lepas dan jurnal sebagai asas kepada rujukan kajian. Kajian ini adalah berbentuk soal selidik yang menggunakan teknik analisis deskriptif dan inferensi. Data-data telah dikutip dari soal selidik dijalankan ke sampel dalam populasi kajian yang merupakan mahasiswa Universiti tempatan. Borang Soal selidik yang mempunyai beberapa bahagian adalah untuk dijawab oleh responden bagi menjawab hipotesis dan persoalan kajian yang telah terwujud. Data-data yang diperoleh dari sampel-sampel ini akan dianalisis dan dipersembahkan dengan statistik deskriptif dan inferensi bagi membincangkan persoalan-persoalan kajian dan objektif kajian. Keputusan analisis akan menunjukkan kesinambungan dan jawapan kepada persoalan-persoalan dan permasalahan kajian yang akan dikaji seterusnya menentukan sama ada hipotesis pengkaji ditolak atau diterima. Data dianalisis menggunakan Google Form sebagai borang soal selidik untuk dijawab oleh responden secara rawak. Selain itu, Google Form juga membantu dalam menganalisis analisis deskriptif seperti Pie Chart untuk Bahagian Demografi. Bagi Analisis Inferensi, pengkaji menggunakan perisian statistik SPSS (Statistical Package For Sosial Sciences) untuk menganalisis data-data seperti min, sisihan piawai, Ujian Kebolehpercayaan dan Ujian Regresi Berganda. 


\section{Hasil Kajian}

Jadual 1 adalah ringkasan kepada latar belakang demografi dan sosioekonomi para responden yang terlibat dalam kajian ini.

Jadual 1: Latar Belakang Demografi

\begin{tabular}{lc}
\hline \multicolumn{1}{c}{ Item } & Kekerapan \\
\hline Jantina & \\
Lelaki & 49 \\
Perempuan & 105 \\
Kaum & \\
Melayu & 142 \\
Cina & 4 \\
India & 3 \\
Lain-lain & 5 \\
Umur & \\
18-20 tahun & 3 \\
$21-23$ tahun & 105 \\
$24-26$ tahun & 35 \\
27 ke atas & 11 \\
Status perkahwinan & \\
Bujang & 151 \\
Berkahwin & 4 \\
Kelayakan Akademik & \\
STPM & 30 \\
Matrikulasi & 100 \\
Diploma & 24 \\
Adakah Institusi mempunyai platform komunikasi atas talian ? & 140 \\
Ya & 14 \\
Tidak & \\
Platform atas talian rasmi institus & 30 \\
Zoom & 100 \\
M-Teams & 20 \\
Google Classroom & 4 \\
\hline Lain-lain & \\
\hline
\end{tabular}

Jadual 2 menunjukkan respons pengguna terhadap peranan faktor interaktiviti dalam komunikasi e pembelajaran. Dalam soal selidik yang telah diedarkan terdapat 7 set soalan berkenaan dengan interaktiviti yang berskala likert. Nilai min tertinggi yang dicatatkan adalah bagi soalan IV1, "Saya mampu berkomunikasi dengan baik dan lancar bersama pensyarah semasa proses e pembelajaran" dengan 3.82 skor min dan 1.011 nilai sisihan piawai. Soalan ini mendapat nilai Min yang sederhana tinggi bermakna ramai yang bersetuju dengan mampu berkomunikasi dan berinteraktiviti dengan baik sesama rakan semasa proses E pembelajaran.. Nilai min yang terendah pula adalah pada soalan IV7, "Kurang terjadi salah faham sepanjang interaktiviti pembelajaran atas talian berbanding interaktiviti pembelajaran tradisional", dengan skor min 2.95 dan sisihan piawai 1.154 yang membawa maksud nilai yang sederhana rendah. Ini menunjukkan ramai yang tidak bersetuju atau neutral dengan persoalan ini.

Jadual 2: Peranan Faktor Interaktiviti dalam Komunikasi e-Pembelajaran

\begin{tabular}{|c|c|c|c|}
\hline$\overline{\text { Min }}$ & & $\begin{array}{l}\text { Sisihan } \\
\text { Piawai }\end{array}$ & $\mathbf{N}$ \\
\hline $\begin{array}{l}\text { 1. Saya mampu berkomunikasi dengan baik dan } \\
\text { 2. lancar bersama pensyarah semasa proses e pembelajarar }\end{array}$ & 3.69 & .959 & 154 \\
\hline $\begin{array}{l}\text { 3. Saya mampu berkomunikasi dengan baik dan lancar } \\
\text { bersama rakan sepanjang proses e pembelajaran }\end{array}$ & 3.82 & 1.011 & 154 \\
\hline
\end{tabular}



4. Diskusi menggunakan komunikasi atas talian semasa e pembelajaran membantu
5. meningkatkan interaktiviti dan prestasi saya
6. Interaktiviti semasa komunikasi atas talian
$3.45 \quad 1.121$
154
7. membantu saya untuk lebih berani untuk tampil berkomunikasi
8. Saya mempunyai persepsi yang positif terhadap kesan interaktiviti dalam komunikasi semasa e pembelajaran pada masa yang akan datang
9. Interaktiviti bersama rakan-rakan semasa komunikasi dalam proses e pembelajaran mengeratkan hubungan anda dengan rakan-
10. rakan walaupun rakan itu tidak dikenali
11. Kurang terjadi salah faham sepanjang interaktiviti pembelajaran atas talian berbanding interaktiviti pembelajaran
12. tradisional

$\begin{array}{lll}3.66 & .966 & 154 \\ 3.56 & 1.079 & 154 \\ & & \\ 2.95 & 1.154 & 154\end{array}$

Jadual 3 menunjukkan respons responden terhadap peranan faktor pengurusan masa dalam komunikasi E-pembelajaran. Terdapat 6 set soalan berskala likert yang telah diedarkan kepada responden. Jumlah skor min tertinggi bagi set soalan ini ialah bagi soalan "Masa yang diperuntukkan untuk berkomunikasi di dalam kelas atas talian mencukupi" dengan skor min 3.41 dan sisihan piawai 1.041 bagi 153 orang responden tidak termasuk satu respons hilang nilai (missing value). Hal ini menunjukkan ramai dari responden bersetuju dengan masa untuk berkomunikasi di dalam kelas atas talian adalah mencukupi. Bagi nilai skor min yang terendah pula, soalan Komunikasi semasa e pembelajaran membazir masa penyampaian maklumat menunjukkan min yang terendah iaitu 2.89 dengan sisihan piawai sebanyak 1.139 bagi 153 orang responden. Hal ini membawa maksud ramai responden yg neutral dan tidak bersetuju berkenaan dengan komunikasi semasa E pembelajaran membazir masa penyampaian maklumat.

\section{Jadual 3: Pengurusan Masa dalam Komunikasi e-Pembelajaran}

\begin{tabular}{|c|c|c|c|c|}
\hline \multicolumn{3}{|c|}{ Min } & \multirow{2}{*}{$\begin{array}{l}\begin{array}{l}\text { Sisihan } \\
\text { Piawai }\end{array} \\
1.139\end{array}$} & \multirow{2}{*}{$\begin{array}{l}\mathbf{N} \\
153\end{array}$} \\
\hline 1. & $\begin{array}{l}\text { Komunikasi semasa e pembelajaran membazir masa penyampaian } \\
\text { maklumat }\end{array}$ & 2.89 & & \\
\hline & $\begin{array}{l}\text { Masa yang diperuntukkan untuk berkomunikasi di dalam kelas atas } \\
\text { talian mencukupi }\end{array}$ & 3.41 & 1.041 & 153 \\
\hline 3. & $\begin{array}{l}\text { Masa perbincangan bersama pensyarah secara persendirian atau } \\
\text { berkumpulan mencukupi dan efektif dalam proses e pembelajaran } \\
\text { berbanding tradisional }\end{array}$ & 2.98 & 1.115 & 153 \\
\hline 4. & $\begin{array}{l}\text { Tiada masalah dari faktor masa dalam komunikasi bersama rakan } \\
\text { semasa proses e pembelajaran (perbincangan kerja } \\
\text { berkumpulan) }\end{array}$ & 3.07 & 1.193 & 153 \\
\hline 6. & $\begin{array}{l}\text { Kemahiran pengurusan masa saya meningkat dengan } \\
\text { menggunakan komunikasi atas talian semasa e pembelajaran }\end{array}$ & 3.21 & 1.080 & 153 \\
\hline 8. & $\begin{array}{l}\text { Saya lebih menghargai masa apabila berkomunikasi secara atas talian } \\
\text { berbanding komunikasi dalam proses pembelajaran tradisional }\end{array}$ & 3.35 & 1.160 & 153 \\
\hline
\end{tabular}

Jadual 4 menunjukkan respons responden terhadap set soalan pemboleh ubah bebas peranan faktor peningkatan pengetahuan ICT dalam komunikasi E pembelajaran. Terdapat 5 Jumlah Set soalan bagi bahagian D ini dan dijawab oleh 153 responden tidak termasuk nilai hilang (missing value). Skor min yang tertinggi adalah bagi soalan Berkomunikasi menggunakan Platform e pembelajaran meningkatkan pengetahuan saya terhadap teknologi komunikasi \& maklumat dengan Min 4.18 dan Sisihan Piawai 0.807 bagi 153 orang responden yang bermaksud ramai bersetuju dengan komunikasi dalam e pembelajaran telah berjaya meningkatkan pengetahuan ICT dalam diri pelajar. Bagi nilai skor 
min terendah pula, Soalan Komunikasi menggunakan platform atas talian menyukarkan saya untuk berkomunikasi kerana keterbatasan pengetahuan ICT (teknologi maklumat dan komunikasi) mendapat skor min terendah dengan nilai min 3.31 dan nilai sisihan piawai 1.161. Hal ini bermaksud ramai yang tidak bersetuju atau neutral dengan persoalan bahawa Kurangnya pengetahuan ICT menyebabkan mereka sukar untuk menggunakan platform berkomunikasi dalam e pembelajaran.

Jadual 4: Peningkatan Pengetahuan ICT dalam Komunikasi e-Pembelajaran

\begin{tabular}{|c|c|c|c|c|}
\hline \multicolumn{3}{|c|}{ Min } & \multirow{2}{*}{$\begin{array}{l}\begin{array}{l}\text { Sisihan } \\
\text { Piawai }\end{array} \\
.807\end{array}$} & \multirow{2}{*}{$\begin{array}{l}\mathbf{N} \\
153\end{array}$} \\
\hline 1. & $\begin{array}{l}\text { Berkomunikasi menggunakan Platform e pembelajaran meningkatkan } \\
\text { pengetahuan saya terhadap teknologi komunikasi \& maklumat ( ICT) }\end{array}$ & 4.18 & & \\
\hline 2. & $\begin{array}{l}\text { Saya menyedari berkenaan kewujudan kemudahan komunikasi ICT } \\
\text { seperti platform e pembelajaran (Zoom, ms team etc.) sebelum } \\
\text { menjalani proses e pembelajaran }\end{array}$ & 3.90 & 1.168 & 153 \\
\hline 3. & $\begin{array}{l}\text { Saya lebih mahir menggunakan pelbagai sistem komunikasi atas } \\
\text { talian untuk berkomunikasi selepas menggunakan platform e } \\
\text { pembelajaran }\end{array}$ & 4.14 & .803 & 153 \\
\hline 4. & $\begin{array}{l}\text { Saya mempunyai persepsi positif berkenaan impak komunikasi e } \\
\text { pembelajaran dalam meningkatkan kemahiran }\end{array}$ & 4.01 & .835 & 153 \\
\hline 5. & ICT ( teknologi maklumat dan komunikasi) pelajar. & & & \\
\hline & $\begin{array}{l}\text { Komunikasi menggunakan platform atas talian menyukarkan } \\
\text { saya untuk berkomunikasi kerana keterbatasan pengetahuan ICT } \\
\text { (teknologi maklumat dan komunikasi) }\end{array}$ & 3.31 & 1.161 & 153 \\
\hline
\end{tabular}

Jadual 5 di bawah menunjukkan nilai min dan sisihan piawai bagi soalan pemboleh ubah bebas iaitu Prestasi pelajar sepanjang E pembelajaran pasca Covid 19. Terdapat 7 set soalan berskala likert yang telah dijawab oleh 153 orang responden tidak termasuk satu nilai hilang (missing values). Jadual di bawah menunjukkan nilai min yang paling tinggi bagi ke-7 set soalan ialah soalan nombor 3 iaitu GPA saya meningkat semasa proses E pembelajaran sepanjang Pandemik Covid 19 dengan skor min sebanyak 3.69 dan sisihan piawai ialah 1.072. Hal ini bermakna majoriti responden bersetuju dengan nilai GPA yang meningkat disebabkan proses pembelajaran secara atas talian. Nilai min yang paling rendah pula bagi 7 set soalan ini ialah nilai min bagi soalan no 6 iaitu Aspek Integriti dalam diri saya menurun sepanjang proses E pembelajaran dengan nilai Min 3.18 dan sisihan piawaian 1.115. Hal ini bermakna pelajar tidak bersetuju dan neutral dengan soalan aspek integriti saya menurun disebabkan proses e pembelajaran.

Jadual 5: Peningkatan Pengetahuan ICT

\begin{tabular}{|c|c|c|c|}
\hline Min & & $\begin{array}{l}\text { Sisihan } \\
\text { Piawai }\end{array}$ & $\mathbf{N}$ \\
\hline $\begin{array}{l}\text { 1. Kemudahan dalam kaedah pembelajaran baru ( e pembelajaran ) } \\
\text { meningkatkan prestasi saya }\end{array}$ & 3.50 & .981 & 153 \\
\hline $\begin{array}{l}\text { 2. Prestasi saya lebih meningkat ketika proses e pembelajaran berbanding } \\
\text { pembelajaran secara tradisional }\end{array}$ & 3.46 & 1.088 & 153 \\
\hline $\begin{array}{l}\text { 3. GPA saya meningkat semasa proses e pembelajaran sepanjang } \\
\text { Pandemik Covid } 19\end{array}$ & 3.69 & 1.072 & 153 \\
\hline $\begin{array}{l}\text { 4. Kemahiran interpersonal saya menurun ketika berkomunikasi secara } \\
\text { atas talian }\end{array}$ & 3.31 & 1.047 & 153 \\
\hline $\begin{array}{l}\text { 5. Saya dapat memproses maklumat dan pengetahuan yang diperolehi } \\
\text { dengan lebih efektif dalam proses e pembelajaran }\end{array}$ & 3.37 & 1.038 & 153 \\
\hline $\begin{array}{l}\text { 6. Aspek Integriti dalam diri saya menurun sepanjang proses e } \\
\text { pembelajaran }\end{array}$ & 3.18 & 1.115 & 153 \\
\hline $\begin{array}{l}\text { 7. Saya memahami sepenuhnya kursus yang dibentangkan oleh Universiti } \\
\text { secara e pembelajaran pasca Covid } 19 \text { berbanding tradisional }\end{array}$ & 3.22 & 1.186 & 153 \\
\hline
\end{tabular}




\section{Ujian Kebolehpercayaan}

Tujuan Ujian ini adalah untuk menentukan sama ada tahap kebolehpercayaan di mana ujian ini akan mengukur tahap kesahihan dan kebolehpercayaan bagi menjamin borang soal selidik yang diedarkan adalah borang soal selidik yang berkualiti dan boleh dipercayai.

Berdasarkan kepada jadual 6 pemboleh ubah tidak bersandar seperti interaktiviti, pengurusan masa, faktor ICT dan prestasi pelajar mempunyai nilai yang melebihi 0.6. Ini menunjukkan keempat-empat pemboleh ubah mempunyai tahap kebolehpercayaan yang boleh diterima

Jadual 6: Ujian Kebolehpercayaan

\begin{tabular}{lcc}
\multicolumn{1}{c}{ Pemboleh ubah } & Cronbach's Alpha & Jumlah item \\
\hline Interaktiviti & .888 & 7 \\
Pengurusan Masa & .777 & 6 \\
Faktor ICT & .675 & 5 \\
Prestasi Pelajar & .784 & 7 \\
\hline
\end{tabular}

\section{Ujian Regresi Berganda}

Dalam menentukan perhubungan antara pemboleh ubah bebas dan bersandar, analisis statistik yang terbaik digunakan adalah analisis kolerasi dan regresi. Analisis kolerasi adalah analisis yang menguji seberapa kuat hubungan antara pemboleh ubah bebas dan bersandar manakala analisis regresi pula menguji wujud atau tidak hubungan antara pemboleh ubah bebas dan bersandar. Bagi pemboleh ubah bebas yang mempunyai kuantiti lebih dari 1, analisis regresi berganda akan digunakan. Di dalam kajian ini, pengkaji telah menggunakan Ujian Regresi Berganda sebagai salah satu kaedah analisis inferensi bagi memperoleh perhubungan antara pemboleh ubah bebas dan pemboleh ubah bersandar.

\begin{tabular}{lll}
\hline $\begin{array}{l}\text { Variables } \\
\text { Model }\end{array} \quad$ Entered & Variables Removed & Method \\
\hline $1 \quad$ ICT, IV, PM & & Enter \\
\hline Nota: & $\cdot$ & \\
ICT - Faktor Teknologi Maklumat Dan Komunikasi & \\
IV - Faktor Interaktiviti & \\
PM - Faktor Pengurusan Masa & \\
PE - Prestasi Pelajar Pasca Covid 19 Dalam E Pembelajaran & \\
a. Dependent Variable: PE & \\
b. All requested variables entered. &
\end{tabular}

Jadual 7: Analis R Square

\begin{tabular}{lllll}
\hline Model & $\mathbf{R}$ & R Square & Adjusted R Square & $\begin{array}{l}\text { Std. Error of the } \\
\text { Estimate }\end{array}$ \\
\hline 1 & $.715^{\mathrm{a}}$ & .511 & .501 & .50043 \\
\hline
\end{tabular}

a. Predictors: (Constant), ICT, IV, PM

b. Dependent Variable: PE

R Square atau R2 di dalam model di atas menunjukkan nilai .511 yang memberi maksud $51 \%$ dari varians untuk Prestasi Pelajar (PE) dapat diperjelaskan oleh pemboleh ubah bersandar yang lain seperti ICT (komunikasi e pembelajaran dan ICT), IV (interaktiviti dalam komunikasi e pembelajaran ) dan PM ( pengurusan masa dan komunikasi e pembelajaran.) Disebabkan R square adalah pengukur bagi (goodness of fit) atau kebaikan dalam penyebaran variasi data, Semakin tinggi peratus R2 mengukur kekuatan hubungan antara model kajian dan pemboleh ubah bebas. Kesimpulannya, $51 \%$ dari varians 
pemboleh ubah bersandar yang menyebar ke pemboleh ubah bersandar menunjukkan hubungan yang kuat antara model dan pemboleh ubah bersandar.

Jadual 8: Analisis F

\begin{tabular}{lllllll}
\hline $\begin{array}{l}\text { Sum of } \\
\text { Model }\end{array}$ & Squares & & df & Mean Square & F & Sig. \\
\hline 1 & Regression & 39.295 & 3 & 13.098 & 52.303 & $.000^{\mathrm{b}}$ \\
& Residual & 37.565 & 150 & .250 & & \\
& Total & 76.861 & 153 & & & \\
\hline
\end{tabular}

Ujian yang ditunjukkan oleh rajah di atas adalah Ujian F. Ujian ini adalah ujian yang dijalankan bersama dengan varians dari pemboleh ubah bebas yang bernilai sama kosong. Jika dilihat dari rajah di atas, Perubahan dalam F value adalah 52.303 dan ianya adalah signifikan dari nilai kosong (0). Kesimpulannya, pekali yang ditambah telah berjaya menambah baik model jika $\mathrm{P}$ value menunjukkan nilai kosong (0) dan signifikan.

Jadual 9: Perhubungan antara pemboleh ubah bersandar dan tidak bersandar

\begin{tabular}{|c|c|c|c|c|c|c|}
\hline Model & & $\begin{array}{l}\text { Unstandardized } \\
\text { Coefficients } \\
\text { B }\end{array}$ & Std. Error & $\begin{array}{l}\text { Standardized } \\
\text { Coefficients } \\
\text { Beta }\end{array}$ & $\mathrm{t}$ & Sig. \\
\hline \multirow[t]{4}{*}{1} & (Constant) & .525 & .262 & & 1.999 & .047 \\
\hline & IV & .190 & .066 & .216 & 2.880 & .005 \\
\hline & PM & .381 & .071 & .413 & 5.394 & .000 \\
\hline & ICT & .252 & .072 & .228 & 3.477 & .001 \\
\hline
\end{tabular}

Kajian ini menggunakan nilai Beta yang dilabel sebagai B dalam jadual di atas untuk menentukan pemboleh ubah bersandar yang mana memberi perhubungan yang kuat dan positif kepada pemboleh ubah bebas iaitu ( prestasi semasa e pembelajaran Covid 19). Keputusan menunjukkan bahawa pekali Beta yang terbesar bagi ketiga-ketiga pemboleh ubah bersandar didahului dengan 0.381, iaitu Pekali bagi pemboleh ubah PM iaitu Pengurusan Masa dalam komunikasi e pembelajaran. Ini membuktikan bahawa PM memberi satu perhubungan yang paling kuat dan unik kepada prestasi pembelajaran sepanjang E-pembelajaran pasca Covid 19. Perkara ini diikuti dengan pemboleh ubah bersandar yang lain iaitu ICT (0.252) dan akhir sekali interaktiviti sebanyak 0.190.Kesimpulannya, keputusan dari analisis mendapati bahawa Pengurusan Masa dalam komunikasi E-pembelajaran $(t=5.394 \mathrm{p}=0.00 \mathrm{~b}=$ 0.381), Pengetahuan IT dan hubungannya dengan komunikasi E pembelajaran (ICT) $(\mathrm{t}=3.4777$ $\mathrm{p}=0.001 \mathrm{~b}=0.252)$, dan Interaktiviti dalam komunikasi e pembelajaran $(\mathrm{t}=2.880 \mathrm{p}=0.005 \mathrm{~b}=0190)$ mempunyai hubungan yang signifikan secara statistik dan memberi satu perhubungan yang positif kepada pemboleh ubah bebas iaitu Prestasi pelajar dalam E-pembelajaran Pasca Covid 19. Kesimpulannya H1a, H1b, H1c dalam kajian ini disokong dan membuktikan bahawa lebih tinggi peratus Pengurusan Masa, ICT, dan Interaktiviti dipraktikkan dalam komunikasi e pembelajaran dapat mempengaruhi perubahan yang positif ke atas prestasi pelajar sepanjang E-pembelajaran pasca Covid 19.

\section{Kesimpulan}

Walaupun keputusan regresi menunjukkan keputusan yang signifikan antara peningkatan interaktiviti dalam komunikasi atas talian kepada prestasi pelajar, terdapat beberapa implikasi yang boleh kita perbaiki dalam kajian akan datang. Hal ini disebabkan skor min terendah bagi set soalan bagi pemboleh ubah bebas faktor interaktiviti menunjukkan nilai min yang rendah iaitu 2.95 sahaja bagi soalan kurang terjadi salah faham antara rakan ketika berkomunikasi dalam E-pembelajaran berbanding pembelajaran tradisional. Seterusnya skor min kedua terendah juga menunjukkan berkenaan proses diskusi iaitu soalan yang berbunyi proses diskusi atas talian meningkatkan prestasi saya yang juga mendapat min kedua terendah iaitu 3.45 berbanding skor min bagi soalan soalan 
yang lain. Antara cadangan-cadangan yang dapat diajukan untuk menyelesaikan masalah ini pada kajian yang akan datang adalah Membuat kajian yang lebih mengkhusus terhadap bagaimana untuk meningkatkan hubungan interaktiviti antara pelajar dan pelajar kerana terdapat min yang rendah di dalam soalan yang menunjukkan terdapat pelajar yang merasakan tidak dapat menetapkan hubungan interaktiviti yang baik bersama rakan-rakan semasa proses komunikasi dalam e pembelajaran. Hal ini disokong lagi dengan soalan sesi berdiskusi secara atas talian meningkatkan prestasi pembelajaran saya yang mendapat skor min kedua terendah iaitu 3.45. Kesimpulannya, Kajian-kajian yang akan datang perlu menumpukan berkenaan dengan bagaimana untuk meningkatkan interaktiviti antara pelajar sesama pelajar di dalam e pembelajaran. Hal ini untuk mengurangkan salah faham. Pengkaji yang akan datang boleh menyediakan sebuah kajian tinjauan yang lebih mengkhusus kepada salah faham yang terjadi semasa proses komunikasi dalam E-pembelajaran yang menyebabkan berlakunya pergaduhan dan salah faham di kalangan pelajar. Pengkaji yang akan datang mungkin boleh mengaplikasikan Teori Penglibatan dari Hrastinski (2009) sebagai salah satu teori utama dalam kerangka kajiannya. Kajian ini akan membantu untuk mencari penyelesaian dan membuat keputusan yang baik bagi meningkatkan mutu pendidikan negara pada masa akan datang.

\section{Rujukan}

Alawamleh, M., Al-Twait, L. M., \& Al-Saht, G. R. (2020). The effect of online learning on communication between instructors and students during Covid-19 pandemic. Asian Education and Development Studies.

Ahmad Elzany, Abir El Sadik, Waleed Al Abdulmonem (2020).Experience of e-learning and online assessment during the COVID-19pandemic at the College of Medicine, Qassim University. Journal Of Taibah University Medical Sciences, 15(6), 456-462

An, Y-J., Aworuwa, B., Ballard, G., \& Williams, K. (2009). Teaching with Web 2.0 Technologies: Benefits, Barriers and Best Practices. Proceedings of the Annual Convention of the AECT, 1-6.

Aris Febri Rahmanto 2004.Peranan Komunikasi Dalam Suatu Organisasi. Jurnal Ilmiah Ilmu Komunikasi, 1(2), 59-75

Aytekin Isman \& Fahriye Altinay 2005. Communication Barriers: A Study of Eastern Mediterranean University Students' and Teachers' of Online Program and Courses, 6(4), 13.

An, Y-J., Aworuwa, B., Ballard, G., \& Williams, K. (2009). Teaching with Web 2.0 Technologies: Benefits, Barriers and Best Practices. Proceedings of the Annual Convention of the AECT, 1-6.

Brown, B. W., \& Liedholm, C. E. (2002). Can web courses replace the classroom in principles of Microeconomics? American Economic Review, 2(2), 444-448

B Venkatashiva Reddy, Arti Gupta. (2020). Importance of effective communication during COVID-19 infodemic. Journal of Family Medicine and Primary Care, 9(8), 3793-3796

Clark, R.C. and Mayer, R.E. (2003), E-learning and the Science of Instruction: Proven Guidelines for Consumers and Designers of Multimedia Learning. Jossey-Bass/Pfeiffer, San Francisco, CA.

Dennis Kira \& Raafat George Saade. (2006). Factors affecting online learning. International Conference on Cognition and Exploratory Learning in Digital Age. 277-282

Devi Ratih Retnowati, Ach. Fatchan, I Komang Astina. (2016). Prestasi Akademik dan Motivasi Berprestasi Mahasiswa S1 Pendidikan Geografi Universitas Negeri Malang 1 (3) 521-525.

Ety Nur Inah (2013). Peranan Komunikasi Dalam Pendidikan. Jurnal Al-Ta'dib, 6(1), 176-178.

EllenRose.(1999). Deconstruction interactivity in educational computing. Educational Technology 39 (1), $43-4$

Eugene Borokhovski \& Rana Tamim, Richard F Schmid, Robert M. Bernard. (2015).TechnologySupported Student Interaction in Post-Secondary Education: A Meta-Analysis of Designed Versus Contextual Treatments

Gerard Goggin \& Katie Ellis. (2020). Disability, communication, and life itself in the COVID-19 pandemic. Health Sociology Review, 29(2),168-176

Heinich, Robert, Molenda, Michael, Russell, James D.1989.Instructional media and the new technologies of instruction.Shauna Schullo,Amy Hilbelink, Melissa Venable,Ann E. Barron.2007.Selecting a Virtual Classroom System: Elluminate Live vs. MacromediaBreeze (Adobe Acrobat Connect Professional). MERLOT Journal of Online Learning and Teaching, 3(4), 332-340 
Irny Suzila Ishak,Rose Alinda Alias. (2005). Designing A Strategic Information Systems Planning Methodology For Malaysian Institutes of Higher Learning (ISP-IPTA) 1 (1) 1-7.

Joann Keyton (2011). Communication and Organizational Culture. A Key to Understanding Work Experience. Thousand Oaks CA : Sag

Lasse Lipponen, Marjaana Veermans, Kai Hakkarainen, Tuire Palonen (2002). J. Educational Computing Research, 27(4) 355-384

McLeod, Saul A. (2018). Maslow's Hierarchy of Needs. Diambil daripada https://www.simplypsychology.org/maslow.html\#gsc.tab=0

Michael Yacci (2000). Interactivity Demystified: A Structural Definition for Distance Education and Intelligent CBT.Educational Technology 1-6.

Ministry of Education Peru (MinEdu). (2007). Supreme Decree 16-2007-ED, Retrieved Fromwww. minedu.gob.pe/normatividad/decretos/DS-016-2007-ED.php (accessed 30 November 2008).

Ministry of Education Peru (MinEdu). (2007). Institutional strategic plan 2007-2011.Retrieved From www.minedu.gob.pe/Publicaciones/PEIMED-05.XI.07.pdf.

Mohammed Arshad Khan,Vivek, Mohammed Kamalun Nabi, Maysoon Khojahand Muhammad Tahir. (2020). Students' Perception towards E-Learning during COVID-19 Pandemic in India: An Empirical Study. 13-57

Patrick Vinck, Yen Phuong Huu Pham, Kenedy K Bindu, Juliet Bedford. (2019). Institutional trust and misinformation in the response to the 2018-19 Ebola outbreak in North Kivu, DR Congo: a population-based survey. The Lancet Infectious Diseases, 19(5).

Philip C. Abrami , Robert M. Bernard, Eva M. Bures. (2011). Interaction in Distance Education and Online Learning: Using Evidence and Theory to Improve Practice. 2010 Research Symposium

Robert M. Bernard, Philip C. Abrami, Eugene Borokhovski, C. Anne Wade, Rana M. Tamim, Michael A. Surkes, and Edward Clement Bethel. (2009). A Meta-Analysis of Three Types of Interaction Treatments in Distance Education, 79(3), 1243-1289

Raymond Chiong, Jelena Jovanovic. (2014). Collaborative Learning in Online Study Groups: An Evolutionary Game Theory Perspective. Journal of Information Technology Education, 11, 8298.

Sireen Khemesh (2017). Effective Communication Techniques. 1-5.

Sook Jung Lee. (2009). Online Communication and Adolescent Social Ties: Who benefits more from Internet use. Journal of Computer-Mediated Communication, 14(3).

Subhashni Appanna (2008). A Review of Benefits and Limitations of Online Learning in the Context of the Student, the Instructor and the Tenured Faculty. International Journal on E-learning 7(1), $5-22$

Sm Alessi \& Stanley Trollip. (2001). Multimedia for Learning: Methods and Development

Stefan Hrastinki. (2009). A theory of online learning as online participation. Computers \& Education, 52(1) 78-82.

T. A Bentley, R.A Haslam (2001). A Comparison of safety practises used by managers of high and low accident rate postal delivery offices. Safety Sciences, 37, 19-37

Tomáš Foltýnek \& Arnost Motycka. (2009).Time Management in E-learning. Reflections and Innovations in Integrating ICT in Education 251-255

Tony Bates. (2001). National Strategies For E-Learning in post-secondary education and training. Fundamental of Educational Planning, 70, 17-44

U.S. Department of Education. (2003). Federal funding for educational technology and how it is used in the classroom: A summary of findings from the Integrated Studies of Educational Technology. Washington, D.C.: Office of the Under Secretary, Policy and Program Studies Service.

Wan Idris Wan Sulaiman \& Maizatul Haizan Mahbob, (2015). Hubungan Komunikasi Keorganisasian Dengan Perancangan Strategik Modal Insan Universiti Kebangsaan Malaysia. Jurnal Komunikasi 31(2) $1-14$

Wan Hussain Wan Ishak, Fadhilah Mat Yamin. (2017). Kesan Pembelajaran Elektronik ke Atas Kemahiran ICT

Pelajar.e Proceeding National Innovation and Invention Competition Through Exhibition (iCompEx'17).

Warschauer, M. (2001). Online communication. In R. Carter \& D. Nunan (Eds.), The Cambridge guide to teaching English to speakers of other languages, 207-212. 